\title{
Development of a controlled-release anti-parkinsonian nanodelivery system using levodopa as the active agent
}

This article was published in the following Dove Press journal:

International Journal of Nanomedicine

15 March 2013

Number of times this article has been viewed

\author{
Aminu Umar Kura' \\ Samer Hasan Hussein $\mathrm{Al} \mathrm{Ali}{ }^{2}$ \\ Mohd Zobir Hussein ${ }^{3}$ \\ Sharida Fakurazi ${ }^{1,4}$ \\ Palanisamy Arulselvan' \\ 'Laboratory of Vaccine and \\ Immunotherapeutics, Institute \\ of Bioscience, ${ }^{2}$ Laboratory of \\ Molecular Biomedicine, Institute of \\ Bioscience, ${ }^{3}$ Materials Synthesis and \\ Characterization Laboratory, Institute \\ of Advanced Technology, ${ }^{4}$ Faculty \\ of Medicine and Health Science, \\ Pharmacology Unit, Universiti Putra \\ Malaysia, Selangor, Malaysia
}

\begin{abstract}
A new layered organic-inorganic nanocomposite material with an anti-parkinsonian active compound, L-3-(3,4-dihydroxyphenyl) alanine (levodopa), intercalated into the inorganic interlayers of a $\mathrm{Zn} / \mathrm{Al}$-layered double hydroxide $(\mathrm{LDH})$ was synthesized using a direct coprecipitation method. The resulting nanocomposite was composed of the organic moiety, levodopa, sandwiched between $\mathrm{Zn} / \mathrm{Al}-\mathrm{LDH}$ inorganic interlayers. The basal spacing of the resulting nanocomposite was $10.9 \AA$. The estimated loading of levodopa in the nanocomposite was approximately $16 \%(\mathrm{w} / \mathrm{w})$. A Fourier transform infrared study showed that the absorption bands of the nanocomposite were characteristic of both levodopa and $\mathrm{Zn} / \mathrm{Al}-\mathrm{LDH}$, which further confirmed intercalation, and that the intercalated organic moiety in the nanocomposite was more thermally stable than free levodopa. The resulting nanocomposite showed sustained-release properties, so can be used in a controlled-release formulation. Cytotoxicity analysis using an MTT assay also showed increased cell viability of 3T3 cells exposed to the newly synthesized nanocomposite compared with those exposed to pure levodopa after 72 hours of exposure.
\end{abstract}

Keywords: levodopa, layered double hydroxide, coprecipitation, sustained release

\section{Introduction}

Levodopa has remained the gold standard symptomatic replacement therapy for Parkinsonism, a progressive neurodegenerative disease, over the past 40 years. However, long-term treatment is often complicated by dyskinesia, a form of motor dysfunction, which is attributed to the discontinuous and intermittent delivery of levodopa to the brain, resulting in nonphysiological pulsatile stimulation of striatal dopamine receptors. ${ }^{1,2}$ Dyskinesia is observed in $40 \%$ of patients with Parkinson disease after 5 years (the honeymoon period) of levodopa use and in over $80 \%$ of patients after 10 years of using levodopa. ${ }^{2}$

Tailored nanoparticles are good drug delivery agents because of their sustainedrelease and controlled-release properties. It is widely believed that reducing the pulsatile stimulation of dopaminergic neurons will reduce the risk of levodopa-induced dyskinesia. $^{2}$

Use of nanotechnology in the medical science field and in nanomedicine has reached an advanced stage, where much research has been conducted on the synthesis of nanoparticles that can be used as delivery tools for anticancer agents, central nervous system tumor agents, ${ }^{3,4}$ antibiotics, ${ }^{5}$ and nonsteroidal anti-inflammatory drugs ${ }^{6}$ in gene delivery and imaging studies. ${ }^{7,8}$

Layered double hydroxides (LDHs), also known as hydrotalcite-like compounds or anionic clays, are a broad class of inorganic lamellar compounds with 
a high capacity for anion intercalation. The chemical composition of LDHs is expressed by the general formula $\left[\mathrm{M}_{1-\mathrm{x}}^{2+} \mathrm{M}_{\mathrm{x}}^{3+}(\mathrm{OH})_{2}\right]^{\mathrm{x}+}\left(\mathrm{A}^{\mathrm{n}-}\right)_{\mathrm{x} / \mathrm{n}} \cdot \mathrm{mH}_{2} \mathrm{O}$ where $\mathrm{M}^{2+}$ and $\mathrm{M}^{3+}$ are divalent and trivalent metal cations, respectively. These hydroxides are derived from brucite $\left[\mathrm{Mg}(\mathrm{OH})_{2}\right]$, and they can be found in nature or be synthesized in a laboratory via coprecipitation method. The interlayer region contains various amounts of water, which is hydrogen-bonded to the hydroxide layers and/or to the interlayer anions. ${ }^{9}$ A characteristic feature of LDH is weak bonding between the interlayer anions and hydroxide sheets that enables exchange of anions. ${ }^{10}$

LDHs are less toxic than other conventional drug carriers and are generally biocompatible, making them an acceptable alternative for drug delivery. ${ }^{11}$ Anionic drugs, such as levodopa, which replace the interlayer anions lying between the two positive metal hydroxide sheets, enable a controllable ion-exchange mechanism. pH dependency and the ability for controlled-release are other advantages of using LDHs as drug delivery systems. Further, the positively charged outer layer of the nanohybrid delivery system, which can attract a negatively charged cell membrane, enables easy penetration of LDH into cells. This type of research has not as yet focused on neurodegenerative diseases. Hence, the aim of this study was to intercalate levodopa into $\mathrm{LDH}$ for the treatment of Parkinson's disease.

\section{Materials and methods Materials}

L-3-(3,4-dihydroxyphenyl) alanine (levodopa, 99\% purity) was purchased from Sigma-Aldrich (St Louis, MO, USA). Other chemicals, including $\mathrm{Zn}\left(\mathrm{NO}_{3}\right)_{2} \cdot 6 \mathrm{H}_{2} \mathrm{O}$ and $\mathrm{Al}\left(\mathrm{NO}_{3}\right)_{3} \cdot 9 \mathrm{H}_{2} \mathrm{O}$, were of analytical grade and used without further characterization. Deionized water was used throughout the experiment, unless stated otherwise.

\section{Synthesis}

$\mathrm{Zn} / \mathrm{Al}-\mathrm{LDH}$ (the nanolayer) was synthesized in nitrate form by adding a solution of sodium hydroxide (1 molar) dropwise to a solution of zinc and aluminum nitrate, with a molar ratio of $2: 1$, in deionized water under a nitrogen atmosphere while vigorously stirring until a $\mathrm{pH}$ of 7.0 was reached. The mixture was aged in an oil bath for 18 hours at $70^{\circ} \mathrm{C}$. The white precipitate obtained was centrifuged, washed three times with deionized water, and dried in an oven overnight at $70^{\circ} \mathrm{C}$. The resulting $\mathrm{Zn} / \mathrm{Al}-\mathrm{LDH}$ was used in a cytotoxicity study and compared with its nanocomposite and levodopa.
Levodopa-Zn/Al-LDH (the nanocomposite) was synthesized using a direct coprecipitation method. In brief, a solution of levodopa (0.08 molar) was added to a $\mathrm{Zn}\left(\mathrm{NO}_{3}\right)_{2} \cdot 6 \mathrm{H}_{2} \mathrm{O}$ and $\mathrm{Al}\left(\mathrm{NO}_{3}\right)_{3} \cdot 9 \mathrm{H}_{2} \mathrm{O}$ solutions, at a ratio of $2: 1$, under constant stirring in the presence of a sustained nitrogen supply at room temperature, and the $\mathrm{pH}$ was adjusted to $7.0 \mathrm{using}$ 1.0 molar $\mathrm{NaOH}$. The experiment was protected from direct sunlight exposure because of the sensitivity of levodopa to light. The mixture was aged at $70^{\circ} \mathrm{C}$ in an oil bath for 18 hours and then centrifuged, filtered, washed with deionized water three times, and dried in an oven overnight.

\section{Controlled-release study}

Drug release profiles were determined at room temperature using phosphate-buffered saline at pH 4.8 and 7.4. Approximately $300 \mathrm{mg}$ of the nanocomposite was added to $500 \mathrm{~mL}$ of the medium. The accumulated amount of levodopa released into the solution was measured at preset time intervals and at $\lambda_{\max }=280 \mathrm{~nm}$ using an ultraviolet-visible spectrophotometer (Lambda 35, Perkin-Elmer, Boston, MA, USA).

\section{Cell culture}

$3 \mathrm{~T} 3$ cells (fibroblasts) were purchased from the American Type Culture Collection ((ATCC), Manassas, VA, USA), cultured in RPMI 1640 medium supplemented with $10 \%$ fetal bovine serum, L-glutamine $15 \mathrm{mmol} / \mathrm{L}$, penicillin $100 \mathrm{U} /$ $\mathrm{mL}$, and streptomycin $100 \mu \mathrm{g} / \mathrm{mL}$, and were then incubated in $5 \% \mathrm{CO}_{2}$ at $37^{\circ} \mathrm{C}$. Cells at $80 \%-90 \%$ confluence were used for seeding and treatment.

\section{Seeding and treatment}

For the cytotoxicity study, cells were seeded in a 96-well plate at a density of $0.5 \times 10^{5}$ cells $/ \mathrm{mL}(100 \mu \mathrm{L} /$ well $)$ and allowed 24 hours to attach before treatment. A stock solution containing $10 \mathrm{mg} / \mathrm{mL}$ of the nanocomposite, the nanohybrid, and levodopa in phosphate-buffered saline was made, diluted in RPMI 1640 complete medium to the desired concentration, and subjected to sonication before being added to the cells. Cell treatment was conducted using a series of dilutions ranging from $150 \mu \mathrm{g} / \mathrm{mL}$ to $0 \mu \mathrm{g} / \mathrm{mL}$ (the control), and readings were taken 72 hours after treatment using a microplate reader (EL $800 \times$, Bio-Tek Instruments Inc, Winooski, VT, USA) after adding MTT (3-(4,5-dimethylthiazol-2-yl)2,5-diphenyltetrazolium bromide). This assay is dependent upon reduction of the tetrazolium salt by mitochondrial dehydrogenase in viable cells, which forms a blue formazan product (Mosmann 1983). ${ }^{12}$ In brief, $20 \mu \mathrm{L}$ of MTT solution ( $5 \mathrm{mg} / \mathrm{mL}$ in phosphate-buffered saline) was added to each 
well, and the plates were kept in an incubator in $5 \% \mathrm{CO}_{2}$ at $37^{\circ} \mathrm{C}$ for 3 hours and centrifuged at $1000 \mathrm{rpm}$ for 5 minutes. The supernatant was discarded, and $100 \mu \mathrm{L}$ of dimethyl sulfoxide was added per well. After keeping this mixture in the dark at room temperature for 30 minutes, absorbance was measured at a wavelength of $570 \mathrm{~nm}$. Experiments were conducted in triplicate, and the cytotoxicity was calculated as:

Cell viability $(\%)=[$ Average $]$ test $/[$ Average $]$ control $\times 100$.

\section{Characterization}

Powder X-ray diffraction patterns were recorded in the $2^{\circ}-60^{\circ}$ range on a diffractometer (XRD-6000, Shimadzu, Tokyo, Japan) using $\mathrm{CuK}_{\alpha}$ radiation $(\lambda=1.5418 \AA)$ at $30 \mathrm{kV}$ and $30 \mathrm{~mA}$, with a dwell time of 4 degrees per minute. The Fourier transform infrared spectra of the materials were recorded at $400-4000 \mathrm{~cm}^{-1}$ using a Thermo Nicolet Nexus FTIR (model Smart Orbit) (International Equipment Trading Ltd. Vernon Hills, IL, USA). The chemical compositions of the samples were analyzed for zinc and aluminum ion content using inductively coupled plasma atomic emission spectrometry (Optima 2000DV, Perkin-Elmer) under standard conditions. An elemental analyzer was used for $\mathrm{C}, \mathrm{H}, \mathrm{N}$, and $\mathrm{S}$ analyses (CHNS-932, LECO Corporation, Saint Joseph, MI, USA). Thermogravimetric and differential thermogravimetric analyses (Mettler Toledo, Columbus, OH, USA) were carried out at a heating rate of $10^{\circ} \mathrm{C}$ per minute from $20^{\circ}$ to $1000^{\circ} \mathrm{C}$ under a nitrogen atmosphere $\left(\mathrm{N}_{2}\right.$ flow rate of $50 \mathrm{~mL}$ per minute). A field emission scanning electron microscope (Nova ${ }^{\mathrm{TM}}$ NanoSEM 230, FEI Company, Hillsboro, OR, USA) was used to determine the surface morphology of the samples.

\section{Results and discussion Powder X-ray diffraction}

The X-ray diffraction patterns of levodopa intercalated into $\mathrm{Zn} / \mathrm{Al}-\mathrm{LDH}$ and of free levodopa are shown in Figure $1 \mathrm{~A}$ and $\mathrm{B}$, respectively. As shown in Figure $1 \mathrm{~A}$, the (003), (006), and (009) reflections were found at $2 \theta$ values of approximately $8.06^{\circ}, 16.04^{\circ}$, and $24.52^{\circ}$, respectively. As reported in the literature, the (003) reflection for the

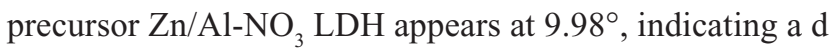
spacing of $8.90 \AA . .^{13}$ The shifting of this reflection toward low $2 \theta\left(2 \theta=8.06^{\circ}\right.$, corresponding to a d spacing of $\left.10.9 \AA\right)$ for the nanocomposite indicates intercalation of levodopa into the interlayer galleries of the $\mathrm{LDH}$. The characteristic reflections of levodopa, shown in Figure 1B, were absent from the X-ray diffraction pattern of the nanocomposite, suggesting that levodopa was intercalated into the interlayer

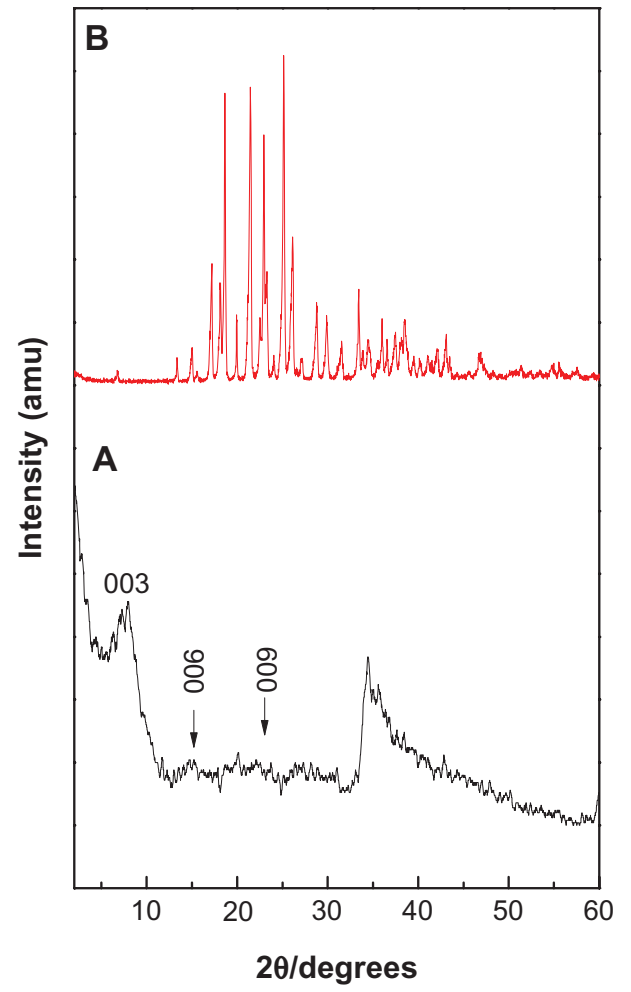

Figure I Powder X-ray diffraction patterns prepared using the coprecipitation method for nanocomposite (A) and levodopa (B).

galleries rather than absorbed at the surface. The broader (003) reflection peak in Figure 1A might have been caused by the formation of a secondary phase due to cointercalation of the counter ion $\left(\mathrm{NO}_{3}^{-}\right)$.

\section{Spatial orientation of intercalated levodopa}

Figure 2A shows the three-dimensional molecular size of levodopa, which was obtained using ChemOffice 2008 software (Cambridge, MA, USA). The long and short axes ( $\mathrm{x}$ axis and $y$ axis, respectively) and molecular thickness ( $\mathrm{z}$ axis) of levodopa were calculated, giving values of $10.4 \AA, 7.1 \AA$, and $6.2 \AA$, respectively. The X-ray diffraction pattern shows a basal spacing (d) of $10.9 \AA$ for the nanocomposite. The thick-

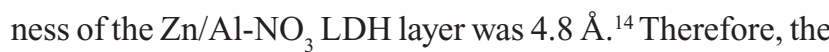
gallery height of LDH after the intercalation processes was $6.1 \AA$ (10.9-4.8 $\AA$ ). This gallery height of the nanocomposite, $6.1 \AA$, is similar to the thickness axis of levodopa (6.2 $\AA$ ). This result indicates that the levodopa anions are accommodated as an alternate monolayer (see Figure 2B).

\section{Infrared spectroscopy}

The Fourier transform infrared spectra for pristine levodopa and levodopa intercalated into the $\mathrm{Zn} / \mathrm{Al}$ interlayer are shown in Figure 3. The spectrum for levodopa (Figure 3A) shows many intense, sharp absorption peaks that arise from the 
A

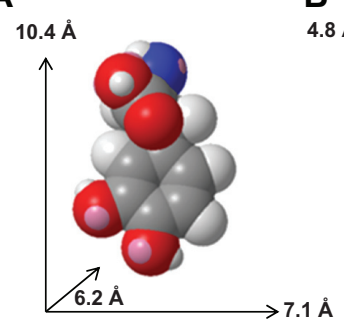

B

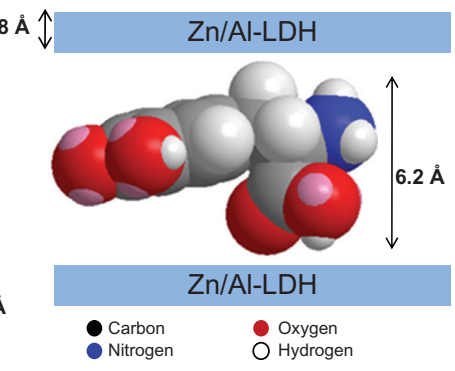

Figure 2 Three-dimensional structure of levodopa (A) and molecular structure model of levodopa intercalated between interlayers of $\mathrm{Zn} / \mathrm{Al}$-layered double hydroxide (B)

Abbreviation: LDH, layered double hydroxide.

different functional groups present in the molecules, ie, the primary amine, carboxylic acid, benzene ring, and hydroxyl groups.

The carboxylic group for levodopa shows three absorption peaks: $1245 \mathrm{~cm}^{-1}$ for the $\mathrm{C}-\mathrm{O}$ stretching, $1739 \mathrm{~cm}^{-1}$ for the $\mathrm{C}=\mathrm{O}$ bond, and a broad band at $1400-1440 \mathrm{~cm}^{-1}$ for the $\mathrm{O}-\mathrm{H}$ bending vibration. The bands at 3353,3189 , and $3035 \mathrm{~cm}^{-1}$ can be attributed to the $\mathrm{v}(\mathrm{N}-\mathrm{H}), \mathrm{v}(\mathrm{O}-\mathrm{H})$, and $\mathrm{v}(\mathrm{Ar}-\mathrm{H})$ vibrations, respectively. The primary amine shows absorption peaks at $1651 \mathrm{~cm}^{-1}$ and $1563 \mathrm{~cm}^{-1}$ that can be attributed to $\mathrm{N}-\mathrm{H}$ bending, while the peaks between $1064 \mathrm{~cm}^{-1}$ and $1200 \mathrm{~cm}^{-1}$ are due to $\mathrm{C}-\mathrm{N}$ stretching, and the peak at approximately $800 \mathrm{~cm}^{-1}$ indicates $\mathrm{N}-\mathrm{H}$ (oop) bending. The band at $1496 \mathrm{~cm}^{-1}$ can be attributed to the $\mathrm{C}=\mathrm{C}$ bond in the benzene ring.

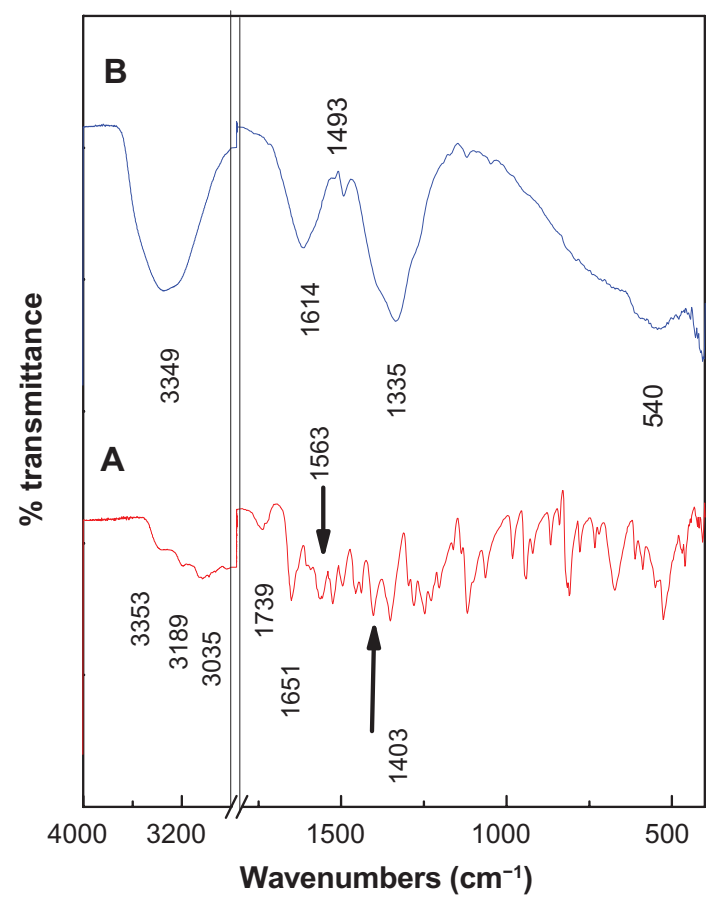

Figure 3 Fourier transform infrared spectra of free levodopa (A) and levodopa-Zn/ Al-layered double hydroxide nanocomposite (B).

The Fourier transform infrared spectrum of the levodopa intercalated into $\mathrm{Zn} / \mathrm{Al}-\mathrm{LDH}$ is shown in Figure 3B. The spectrum of the nanocomposite shows the characteristic bands of pure levodopa, which indicate that the levodopa anions were intercalated into the interlayer galleries of LDH. Some of the bands are slightly shifted. For example, the position of the band for the $\mathrm{C}=\mathrm{C}$ bond shifted from $1496 \mathrm{~cm}^{-1}$ for free levodopa to $1493 \mathrm{~cm}^{-1}$ for the nanocomposite, and the band at $1118 \mathrm{~cm}^{-1}$ for the $\mathrm{C}-\mathrm{N}$ bond shifted to $1120 \mathrm{~cm}^{-1}$; these shifts are due to the interaction between the levodopa anion and the interlayers as a result of the intercalation process. The appearance of a new broad peak at $1614 \mathrm{~cm}^{-1}$ for the nanocomposite can be assigned to the asymmetric stretching vibration of the $\mathrm{COO}^{-}$group. ${ }^{14}$ The band at $1335 \mathrm{~cm}^{-1}$ is due to the nitrate anion, which may not be completely removed from the interlayers during the intercalation process. ${ }^{15}$

\section{Elemental analysis}

Elemental (CHNS) and inductively coupled plasma analyses were conducted to determine the organic and inorganic compositions of the nanocomposite. As expected, the levodopa-nanocomposite contained both organic and inorganic constituents. This result indicates that the levodopa was incorporated into the $\mathrm{Zn} / \mathrm{Al}-\mathrm{LDH}$ inorganic interlayers.

The percentage loading of levodopa in the nanocomposite is $16.00 \%$, as shown in Table 1 . The $\mathrm{C} / \mathrm{N}$ ratio for free levodopa is 8.09 , and this value is higher than the $\mathrm{C} / \mathrm{N}$ ratio of the nanocomposite, possibly indicating that the nitrate anion was not completely removed from the interlayers during the intercalation process. This result was confirmed by the presence of a very broad peak at low $2 \theta$ in the X-ray diffraction pattern. From the elemental chemical analysis and thermogravimetric studies, the empirical formula for the nanocomposite can be proposed as: be $\left[\mathrm{Zn}_{0.64} \mathrm{Al}_{0.36}(\mathrm{OH})_{2}\right](\text { levodopa })_{0.09}\left(\mathrm{NO}_{3}^{-}\right)_{0.27} \cdot 3.03 \mathrm{H}_{2} \mathrm{O}$.

\section{Thermal analysis}

The thermal behavior of the compounds before and after intercalation of levodopa into $\mathrm{Zn} / \mathrm{Al}$-LDH was examined using thermogravimetric and derivative thermogravimetric analysis. The thermograms of levodopa and the nanocomposite are shown in Figure 4. The free levodopa (Figure 4A) thermal decomposition exhibited two weight loss events above $270^{\circ} \mathrm{C}$. The first sharp event occurred at $288^{\circ} \mathrm{C}$ with a weight loss of $42.0 \%$, which was due to the decomposition of levodopa. The second weight loss at $381^{\circ} \mathrm{C}-666^{\circ} \mathrm{C}$ can be attributed to the combustion of levodopa.

After the intercalation process, the thermal decomposition characteristics of the resulting product were different from 
Table I Elemental chemical compositional for free levodopa and its nanocomposite

\begin{tabular}{lllllllll}
\hline Sample & $\mathbf{Z n} \%^{\mathrm{a}}$ & $\mathbf{A l} \%^{\mathrm{a}}$ & $\mathbf{C} \%^{\mathrm{b}}$ & $\mathbf{N} \%^{\mathrm{b}}$ & $\mathbf{C} / \mathbf{N}$ & Drug\% $^{\mathrm{b}}$ & $\mathbf{Z n}^{2+} /\left.\mathbf{A}\right|^{3+}$ & $\mathbf{X}$ \\
\hline Levodopa & - & - & 55.69 & 6.88 & 8.09 & - & - & - \\
Nanocomposite & 16.44 & 3.85 & 8.56 & 4.62 & 1.85 & 16.00 & 1.80 & 0.36 \\
\hline
\end{tabular}

Notes: ${ }^{\mathrm{C} C a l c u l a t e d ~ f r o m ~ i n d u c t i v e l y ~ c o u p l e d ~ p l a s m a ~ d a t a ; ~}{ }^{\mathrm{b}}$ calculated from CHNS elemental data.

Abbreviations: $\mathrm{Zn}$, zinc; $\mathrm{Al}$, aluminium; C, carbon; $\mathrm{N}$, nitrogen; $\mathrm{X}$, aluminium mole fraction = mole of $\mathrm{Al} /(\mathrm{mole}$ of $\mathrm{Al}+\mathrm{mole}$ of $\mathrm{Zn})$.

those of the precursor. The thermal decomposition of the nanocomposite was characterized by two weight loss events, one at $35^{\circ} \mathrm{C}-162^{\circ} \mathrm{C}$ with a weight loss of $31.0 \%$, due to the removal of the external surface-adsorbed and interlayer water molecules, and a second event at $162^{\circ} \mathrm{C}-960^{\circ} \mathrm{C}$ with a weight loss of $30.0 \%$. This second weight loss was due to dehydroxylation of the layers and decomposition of levodopa.

\section{Surface properties}

In Figure 5, the surface morphologies of the $\mathrm{Zn} / \mathrm{Al}$-nanolayer (A and B) and levodopa-nanocomposite (C) are shown. The micrographs were obtained using field emission scanning electron microscopy at (A) $8000 \times$, (B) $15,000 \times$, and (C) 30,000× magnifications. Zn/Al-LDH and the nanocomposite show nonuniform, irregular agglomerates with compact and nonporous plate-like structures, which are commonly observed for LDH and its nanocomposites.

\section{Release behavior of levodopa}

\section{from the Zn/Al-levodopa nanocomposite}

Typical release behavior profiles of levodopa from its nanocomposite at different $\mathrm{pHs}$ are shown in Figure 6, indicating that the release rate of levodopa from the nanocomposite is $\mathrm{pH}$-dependent. The release rate at $\mathrm{pH} 7.4$ is remarkably lower than that at $\mathrm{pH} 4.8$. The percentage release of levodopa from the nanocomposite reaches approximately $74 \%$ within 2400 minutes when exposed to a $\mathrm{pH}$ of 4.8 . When the $\mathrm{pH}$ is changed to 7.4 , the release rate of levodopa from the nanocomposite is obviously lower. The time for $76 \%$ of the drug to be released from the nanocomposite is approximately 8600 minutes. This lower release rate of levodopa from the nanocomposite at $\mathrm{pH} 7.4$ indicates that the levodopa- $\mathrm{Zn} / \mathrm{Al}$ nanocomposite is indeed a potential drug delivery system. The difference in the release rates at $\mathrm{pH} 4.8$ and $\mathrm{pH} 7.4$ may be due to the difference in the release mechanism of levodopa from the nanocomposite. ${ }^{16}$ At an acidic/lower $\mathrm{pH}$ of 4.8 , $\mathrm{Zn} / \mathrm{Al}-\mathrm{LDH}$ begins to dissolve. At $\mathrm{pH} 7.4$, the $\mathrm{Zn} / \mathrm{Al}-\mathrm{LDH}$ is more stable because of electrostatic interaction between the levodopa anions and the positively charged $\mathrm{Zn} / \mathrm{Al}-\mathrm{LDH}$ layers. Thus, the release mechanism at $\mathrm{pH} 4.8$ should occur through both dissolution of the LDH layers and ion exchange, while the mechanism at $\mathrm{pH} 7.4$ should occur via ion exchange with the ions in the buffer solution. ${ }^{16}$

\section{Release kinetics of levodopa from the $\mathrm{Zn} / \mathrm{Al}$-levodopa nanocomposite}

To investigate the exact mechanism of levodopa release from the $\mathrm{Zn} / \mathrm{Al}$-LDH interlayer, the release profile data were fitted using mathematical models that describe various kinetics. The pseudo-first order kinetics mathematical model equation $\ln \left(\mathrm{q}_{\mathrm{e}}-\mathrm{q}_{\mathrm{t}}\right)=\ln \mathrm{q}_{\mathrm{e}}-\mathrm{k}_{\mathrm{l}} \mathrm{t}\left(\mathrm{q}_{\mathrm{e}}\right.$ and $\mathrm{q}_{\mathrm{t}}$ are the equilibrium release amount and the release amount at time $t$, respectively), ${ }^{17}$ the pseudo-second order equation $\mathrm{t} / \mathrm{q}_{\mathrm{t}}=1 / \mathrm{k}_{2} \mathrm{q}_{\mathrm{e}}{ }^{2}+\mathrm{t} / \mathrm{q}_{\mathrm{e}}{ }^{18}$ and the parabolic diffusion equation $\left(1-\mathrm{M}_{\mathrm{t}} / \mathrm{M}_{\mathrm{o}}\right) / \mathrm{t}=\mathrm{kt}^{-0.5}+\mathrm{b}\left(\mathrm{M}_{\mathrm{o}}\right.$ and $\mathrm{M}_{\mathrm{t}}$ are the drug content that remained in LDH at the release times of 0 and $t$, respectively) ${ }^{19}$ were used.
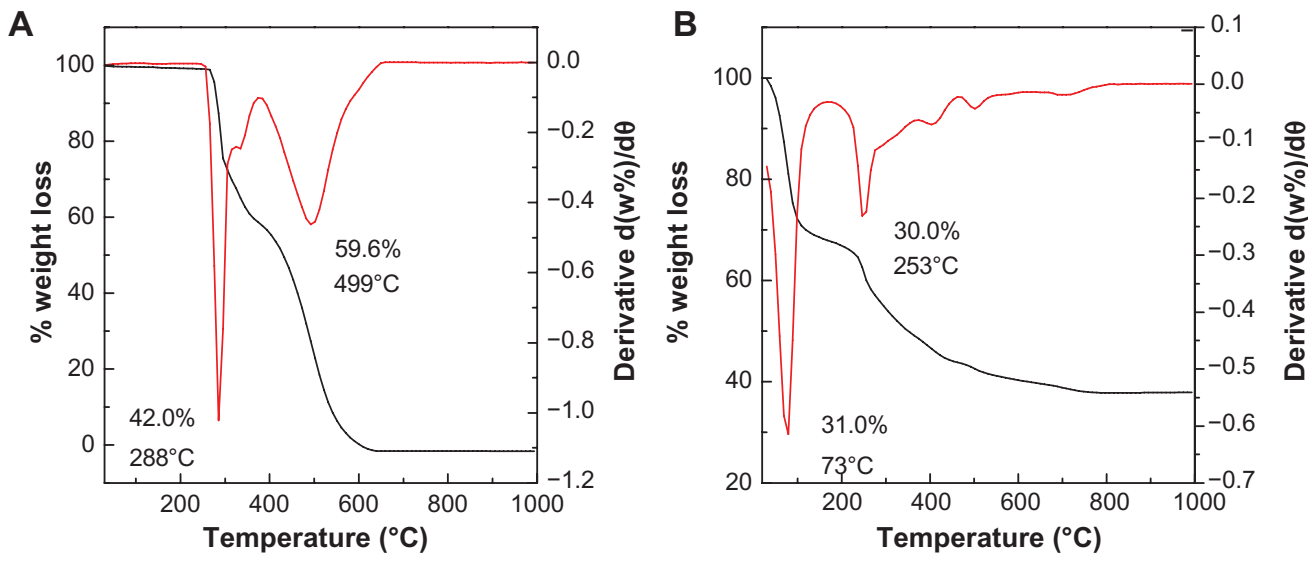

Figure 4 Thermogravimetric and differential thermogravimetric thermograms of levodopa (A) and levodopa-nanocomposite (B). 

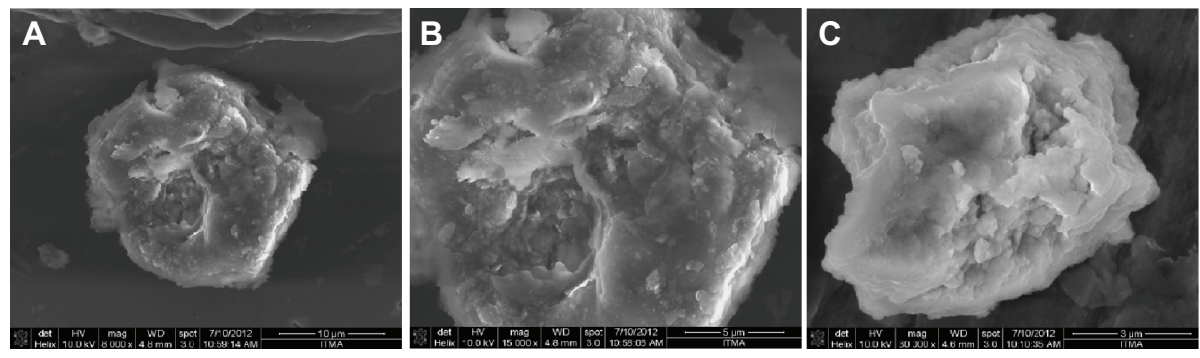

Figure 5 Field emission scanning electron micrographs of $\mathrm{Zn} / \mathrm{Al}$-layered double hydroxide (A and $\mathbf{B})$, and of the Zn/Al-layered double hydroxide-levodopa nanocomposite (C).

The fitting results of the drug release profiles at $\mathrm{pH} 7.4$ and 4.8 based on the three different kinetic models are shown in Figure 7. The correlation coefficient $\left(\mathrm{R}^{2}\right)$ is tabulated in Table 2. From Table 2, it can be seen that the release of levodopa from $\mathrm{Zn} / \mathrm{Al}-\mathrm{LDH}$ follows the pseudo-second order equation very well for both $\mathrm{pH}$ values, with satisfactory coefficients of $0.9988(\mathrm{pH} \mathrm{7.4})$ and $0.9952(\mathrm{pH} 4.8)$. The rate constant for the pseudo-second order equation is $2.85 \times 10^{-5} \mathrm{mg}$ per minute and $4.29 \times 10^{-5} \mathrm{mg}$ per minute at $\mathrm{pH} 7.4$ and $\mathrm{pH} 4.8$, respectively (Table 2). The kinetic results obtained during this work are very similar to those from a kinetic study of the release of camptothecin from $\mathrm{Mg} / \mathrm{Al}-\mathrm{LDH}^{16}$ and are also similar to those for perindopril erbumine intercalated into $\mathrm{Zn} / \mathrm{Al}-\mathrm{LDH}$ using the ion-exchange and coprecipitation methods. ${ }^{20}$

\section{Cytotoxicity analysis of the} nanocomposite, nanohybrid, and levodopa Compared with the control, cell viability was found to decrease with increasing concentrations of levodopa, the nanolayer, and the nanocomposite. The $3 \mathrm{~T} 3$ cell viability was reduced by approximately $40 \%$ when the concentration of levodopa was more than $50 \mu \mathrm{g} / \mathrm{mL}$. For the nanolayer

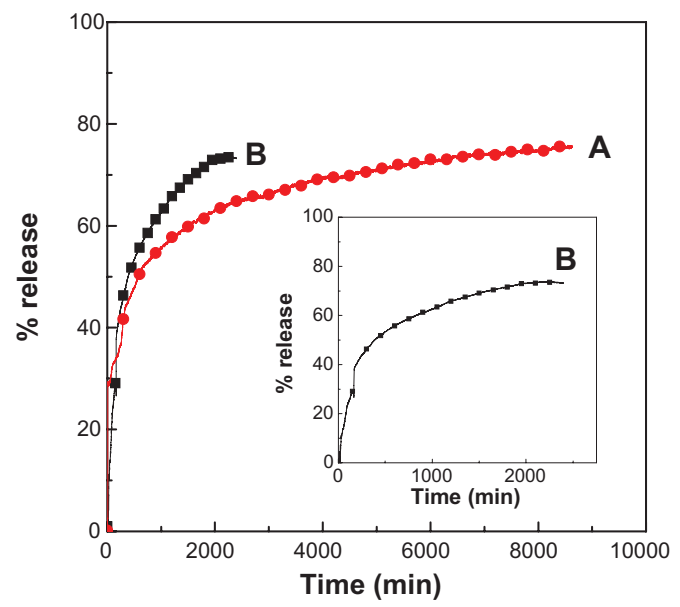

Figure 6 Release profiles of levodopa from the nanocomposite at $\mathrm{pH} 7.4(\mathbf{A})$ and $\mathrm{pH} 4.8$ (B).

Note: Inset shows the release profiles of levodopa from the nanocomposite at $\mathrm{pH}$ 4.8 from 0 to 2000 minutes. alone, cell viability was reduced by more than $40 \%$ when the concentration of the hybrid exceeded $100 \mu \mathrm{g} / \mathrm{mL}$. We observed that the levodopa nanocomposite reached a higher cell viability compared with the carrier nanolayer or with the drug alone in a dose-dependent manner after 72 hours of exposure, as shown in Figure 8.

In vitro, cytotoxicity testing is an essential step in analyzing the health hazards of synthesized nanomaterials in terms of the cellular response to a toxicant for a biomedical application. Therefore, in the present study, we investigated the cytotoxic effect of the synthesized nanocomposite, nanohybrid, and pristine levodopa doses using a biological model with $3 \mathrm{~T} 3$ fibroblast cells and an MTT assay.

It was found that exposure to the nanocomposite at a dose level of $5-150 \mu \mathrm{g} / \mathrm{mL}$ caused dose-dependent cytotoxicity in $3 \mathrm{~T} 3$ cells, as shown in Figure 8, but the same dose of pristine levodopa but more cytotoxicity after 72 hours of exposure compared with the nanocomposite. Findings by other researchers have demonstrated a similar pattern of toxicity in primary rat hepatocytes after exposure to allergic acid and its nanocomposite, ie, the allergic acid caused more toxicity compared with its nanocomposite using the same dose range after 6 hours of exposure. ${ }^{21}$

Our results also demonstrated more toxicity in $3 \mathrm{~T} 3$ cells following exposure to the nanolayer compared with exposure to the nanocomposite at the same doses after 72 hours. In previously reported studies, a decrease in the viability of human umbilical vein endothelial cells was observed following exposure to an LDH nanolayer compared with that following exposure to its nanocomposite, which was functionalized by poly(sulfobetaine). ${ }^{22}$ Meanwhile, in another report, Chang liver cells exposed to an LDH nanolayer also exhibited a slight decrease in viability compared with those exposed to its nanocomposite containing cetirizine.$^{23}$ Our findings are supported by the above-mentioned studies using nanolayers and their corresponding nanocomposites. The results also indicate that our nanocomposite is likely to be a biocompatible product because it shows less cytotoxicity than pristine 

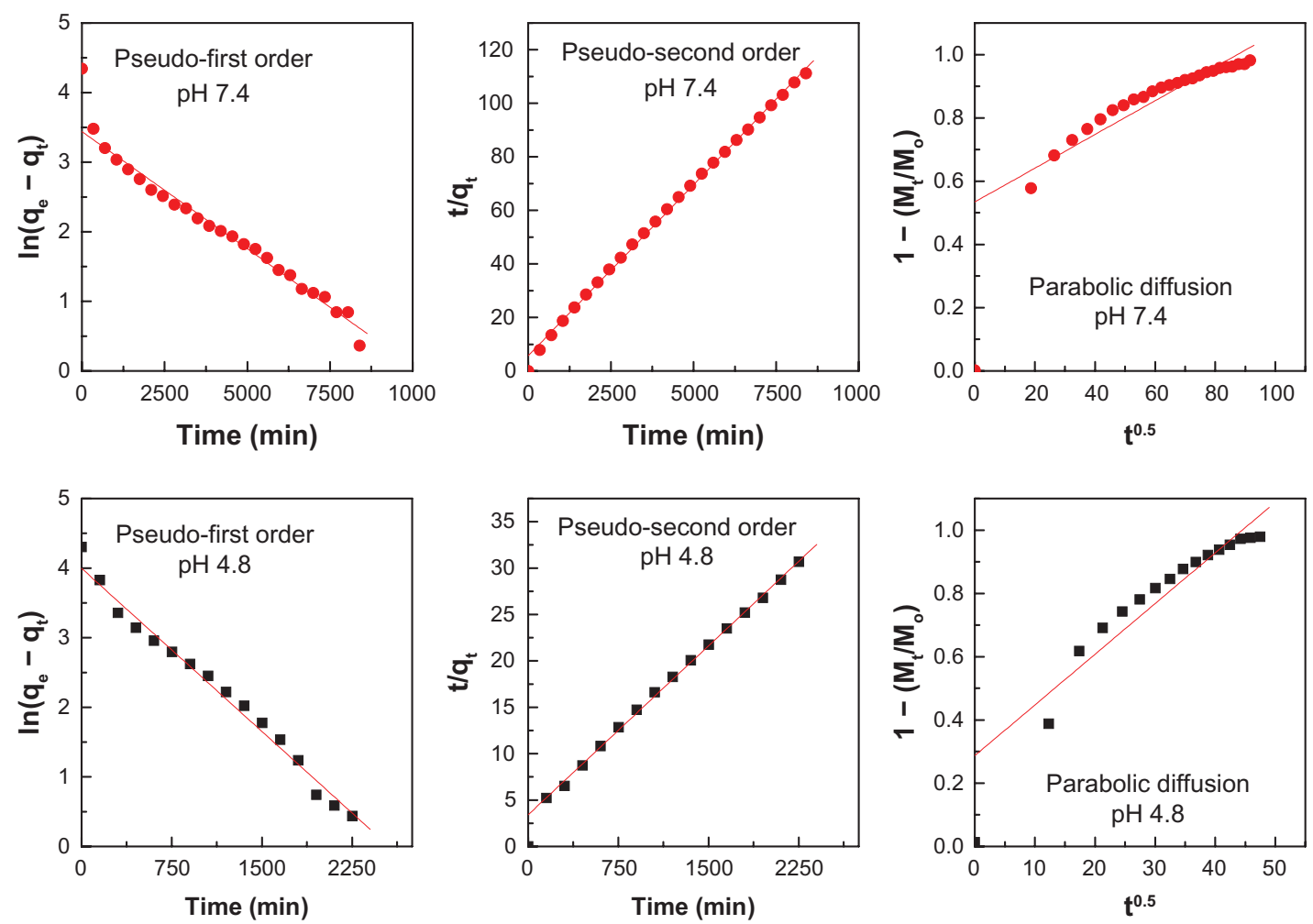

Figure 7 Fits of the levodopa release data for the nanocomposite to the pseudo-first and pseudo-second order kinetics models as well as to the parabolic diffusion model at $\mathrm{pH} 7.4$ and 4.8 .

Table 2 Correlation coefficients $\left(R^{2}\right)$, and rate constants $(k)$ obtained by fitting the levodopa release data for the nanocomposite in solutions at $\mathrm{pH} 4.8$ and 7.4

\begin{tabular}{llllll}
\hline pH & $\begin{array}{l}\text { Saturation } \\
\text { release (\%) }\end{array}$ & $\mathbf{R}^{2}$ & & $\begin{array}{l}\text { Pseudo-second } \\
\text { order }\end{array}$ \\
\cline { 3 - 5 } & $\begin{array}{l}\text { Pseudo-first } \\
\text { order }\end{array}$ & $\begin{array}{l}\text { Pseudo-second } \\
\text { order }\end{array}$ & $\begin{array}{l}\text { Parabolic diffusion } \\
\text { model }\end{array}$ & $\begin{array}{l}\text { Rate constant k } \\
\text { (mg/min) } \times \mathbf{~ 1 0}^{-5}\end{array}$ \\
\hline 7.4 & $76 \%$ & 0.9839 & 0.9988 & 0.8682 & 2.85 \\
4.8 & $74 \%$ & 0.9845 & 0.9952 & 0.8838 & 4.29 \\
\hline
\end{tabular}

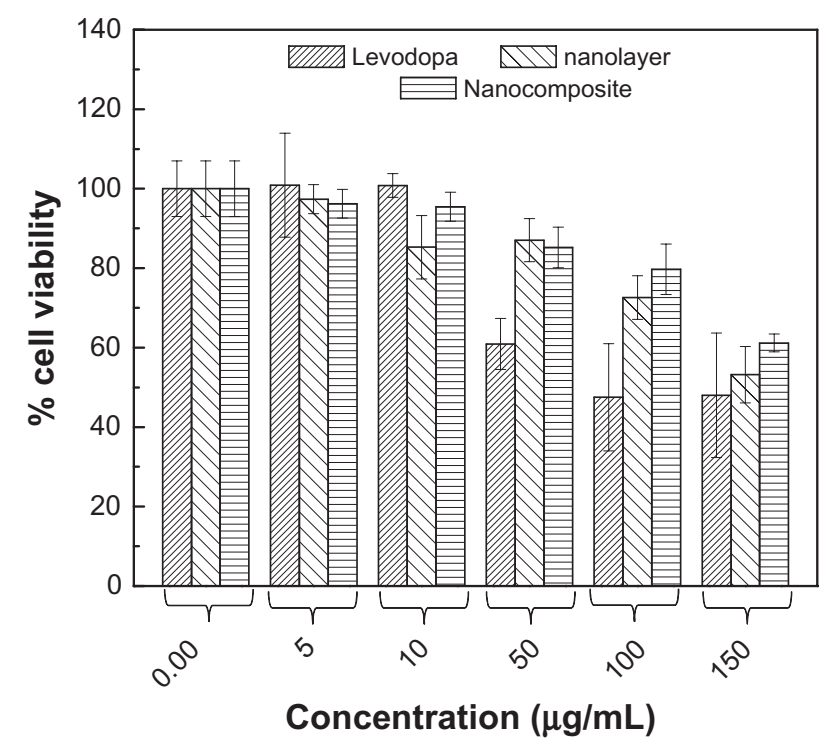

Figure 8 In vitro cytotoxicity study of 3 T3 cells after 72 hours of exposure to free levodopa, the nanolayer, and the levodopa nanocomposite.

Notes: Using the graph as well as regression analysis, the $\mathrm{IC}_{50}$ (concentration of the drug required to induce $50 \%$ cell mortality) for the nanocomposite, nanolayer, and levodopa was $202 \pm 3.55 \mu \mathrm{g} / \mathrm{mL}, 161 \pm 6.42 \mu \mathrm{g} / \mathrm{mL}$, and $73 \pm 6.46 \mu \mathrm{g} / \mathrm{mL}$, respectively $(P<0.005$ for all three, showing statistical significance compared with the control). 
levodopa, which is very important for the potential use of the nanocomposite in an in vivo study.

\section{Conclusion}

Levodopa-Zn/Al-LDH nanocomposites were synthesized using the coprecipitation method with a basal spacing of $10.9 \AA$ and $16.0 \%$ (w/w) loading of levodopa. The intercalation of levodopa into the interlayer spacing of $\mathrm{LDH}$ is shown by Fourier transform infrared spectra. The intercalated guest molecules of levodopa were found to be arranged in a monolayer manner between the inorganic interlayers. Release of levodopa from the nanocomposite was found to be governed by pseudo-second order kinetics, and the release time of levodopa from the nanocomposite at $\mathrm{pH} 7.4$ was longer than that at $\mathrm{pH}$ 4.8. The cytotoxicity study also demonstrated a decrease in the toxicity potential of levodopa in a normal cell line following its intercalation into $\mathrm{Zn} / \mathrm{Al}-\mathrm{LDH}$. Hence, successful intercalation of levodopa may improve drug delivery systems for the treatment of parkinsonism as well as decrease its potential toxicity to cells.

\section{Acknowledgment}

We would like to thank the Ministry of Science, Technology, and Innovation Malaysia for project funding under nanofund NND/NA/(I) TD11-010.

\section{Disclosure}

The authors report no conflicts of interest in this work.

\section{References}

1. Poewe W, Antonini A, Zijlmans JCM, Burkhard PR, Vingerhoets F. Levodopa in the treatment of Parkinson's disease: an old drug still going strong. Clin Interv Aging. 2010;5:229-238.

2. Aviles-Olmos I, Martinez-Fernandez R, Foltynie T. L-dopa-induced dyskinesias in Parkinson's disease. Eur Neurol J. 2010;2(2):91-100.

3. Choi SJ, Oh JM, Choy JH. Anticancer drug-layered hydroxide nanohybrids as potent cancer chemotherapy agents. J Phys Chem Solids. 2008; 69(5-6):1528-1532.

4. Vergoni AV, Tosi G, Tacchi R, Vandelli MA, Bertolini A, Costantino L. Nanoparticles as drug delivery agents specific for CNS: in vivo biodistribution. Nanomedicine. 2009;5(4):369-377.

5. Silion M, Popa MI, Lisa G, Hritcu D. New hybrid compounds containing intercalated ciprofloxacin into layered double hydroxides: synthesis and characterization. Revue Roumaine de Chimie. 2008;53(9):827-831.
6. Del Arco M, Cebadera E, Gutierrez S, et al. Mg, Al layered double hydroxides with intercalated indomethacin: synthesis, characterization, and pharmacological study. J Pharm Sci. 2004;93(6):1649-1658.

7. Wong Y, Markham K, Xu ZP, et al. Efficient delivery of siRNA to cortical neurons using layered double hydroxide nanoparticles. Biomaterials. 2010;31(33):8770-8779.

8. Flesken-Nikitin A, Toshkov I, Naskar J, et al. Toxicity and biomedical imaging of layered nanohybrids in the mouse. Toxicol Pathol. 2007;35(6):804-810.

9. Xu ZP, Lu GQ. Layered double hydroxide nanomaterials as potential cellular drug delivery agents. Pure Appl Chem. 2006;78(9): 1771-1780.

10. Kovanda F, Jindova E, Dousova B, Kolousek D, Plestil J, Sedlakova Z. Layered double hydroxides intercalated with organic anions and their application in preparation of $\mathrm{LDH} /$ polymer nanocomposites. Acta Geodyn Geomater. 2009;6:111-119.

11. Li F, Jin L, Han J, Wei M, Li C. Synthesis and controlled release properties of prednisone intercalated $\mathrm{Mg}$-Al layered double hydroxide composite. Ind Eng Chem Res. 2009;48(12):5590-5597.

12. Mosmann T. Rapid colorimetric assay for cellular growth and survival: Application to proliferation and cytotoxicity assays. J Immunol Methods. 1983;65(1-2):56-83.

13. Xia SJ, Ni ZM, Xu Q, Hu BX, Hu J. Layered double hydroxides as supports for intercalation and sustained release of antihypertensive drugs. J Solid State Chem. 2008;181(10):2610-2619.

14. Al Ali SHH, Al-Qubaisi M, Hussein MZ, Ismail M, Zainal Z, Hakim MN. Controlled release and angiotensin-converting enzyme inhibition properties of an antihypertensive drug based on a perindopril erbumine-layered double hydroxide nanocomposite. Int J Nanomedicine. 2012;7: 2129-2141.

15. Yaghi OM, Li H. T-Shaped molecular building units in the porous structure of Ag (4, 4'-bpy). $\mathrm{NO}_{3}$. J Am Chem Soc. 1996;118(1):295-296.

16. Tyner KM, Schiffman SR, Giannelis EP. Nanobiohybrids as delivery vehicles for camptothecin. J Control Release. 2004;95(3):501-514.

17. Dong L, Yan L, Hou W-G, Liu S-J. Synthesis and release behavior of composites of camptothecin and layered double hydroxide. J Solid State Chem. 2010;183(8):1811-1816.

18. Ho YS, Ofomaja AE. Pseudo-second-order model for lead ion sorption from aqueous solutions onto palm kernel fiber. J Hazard Mater. 2006; 129(1-3):137-142.

19. Kong X, Shi S, Han J, Zhu F, Wei M, Duan X. Preparation of glycy1-tyrosine intercalated layered double hydroxide film and its in vitro release behavior. Chem Eng J. 2010;157(2-3):598-604.

20. Al Ali SHH, Al-Qubaisi M, Hussein MZ, Zainal Z, Hakim MN. Controlled release and angiotensin-converting enzyme inhibitor properties of an antihypertensive drug based on a perindopril erbumine-layered double hydroxide nanocomposite. Int J Nanomedicine. 2012;7:2129-2141.

21. Hussein MZ, Al Ali SH, Zainal Z, Hakim MN. Development of antiproliferative nanohybrid compound with controlled release property using ellagic acid as the active agent. Int J Nanomedicine. 2011;6: 1373-1383.

22. Xu FJ. Preparation and evaluation of well-defined hemocompatible layered double hydroxide-poly (sulfobetaine) nanohybrids. $J$ Mater Chem. 2012;22(30):15362-15369.

23. Hussein-Al-Ali SH, Al-Qubaisi M, Hussein MZ, Ismail M, Zainal Z, Hakim MN. In vitro inhibition of histamine release behavior of cetirizine intercalated into $\mathrm{Zn} / \mathrm{Al}$-and $\mathrm{Mg} / \mathrm{Al}$-layered double hydroxides. Int $\mathrm{J} \mathrm{Mol}$ Sci. 2012;13(5):5899-5916.
International Journal of Nanomedicine

\section{Publish your work in this journal}

The International Journal of Nanomedicine is an international, peerreviewed journal focusing on the application of nanotechnology in diagnostics, therapeutics, and drug delivery systems throughout the biomedical field. This journal is indexed on PubMed Central, MedLine, CAS, SciSearch ${ }^{\circledR}$, Current Contents ${ }^{\circledR} /$ Clinical Medicine,

\section{Dovepress}

Journal Citation Reports/Science Edition, EMBase, Scopus and the Elsevier Bibliographic databases. The manuscript management system is completely online and includes a very quick and fair peer-review system, which is all easy to use. Visit http://www.dovepress.com/ testimonials.php to read real quotes from published authors. 